\title{
Does finance matter for growth in the small, open Pacific Island Countries?
}

\author{
Parmendra Sharma and Neelesh Gounder
}

\begin{abstract}
A body of evidence accumulated over the past several years, via different methods and estimation techniques, using firm-and household-level data, across many regions and countries show that finance matters for growth. Yet the role of finance in fostering growth in the Pacific, ironically, a region in dire need of sustainable growth and development, continues to appear less important, possibly for the reason that the relationship in the case of the region is not properly understood, due in turn to perhaps a lack of systematic empirical evidence. This study provides a first cross-country insight into the finance-growth nexus in the Pacific. Results, using balanced panel data extending 25 years, and the dynamic Generalised Method of Moments (GMM) estimation technique, show that finance is likely to matter for growth in the small, open Pacific Island Countries as well. Our findings strengthen the growing finance-growth literature, further alleviate scepticisms that may arise from shortcomings of different methods and estimation techniques, and have important policy implications for the Pacific.
\end{abstract}

Key words: Finance, economic growth, Pacific Island countries, panel data 


\section{INTRODUCTION}

Not long ago, finance was but only a postscript in the minds of development economists designing a policy agenda. Today, it is an integral part in the debate on how growth can be fostered in developing economies, how poverty levels can be reduced, how problems of inequality may be managed and indeed, how the Millennium Development Goals (MDGs) may be accomplished. Allowing even for reverse causation, research shows, through a number of cross-country, panel, and time-series estimation techniques, strong and positive link between financial sector deepening and economic growth and development. It is now widely regarded that financial development, which involves the establishment and expansion of financial institutions, instruments and markets, is important for long term sustainable economic growth. In particular, financial development supports the growth process by mobilising domestic and foreign savings for investment and ensuring that these funds are diverted to the most productive use. On the whole, financial systems serve five broad functions: (i) produce information ex ante about possible investments; (ii) mobilise and pool savings and allocate capital; (iii) monitor investments and exercise corporate governance after providing finance; (iv) facilitation of trading, diversification and management of risk; and (v) ease the exchange of goods and services (Fitzgerald, 2009). While all financial systems may provide the five functions, the impact on economic growth depends on how well these are provided. The impacts of these functions on economic growth are captured by three basic characteristics of financial systems: (i) the level of financial intermediation; (ii) the efficiency of financial intermediation; and (iii) the composition of financial intermediation. For an overview of the extensive finance-growth literature, see Levine (2005) and Beck (2009).

As illustrated by Beck et al. (2011), for example, in the 1980-2007 period, countries with higher levels of private sector credit relative to GDP experienced higher average annual real GDP per capita growth. The finance-growth relationship is not only statistically but also economically significant. Comparing the case of Ethiopia with Thailand, based on the foregoing cross-country findings, the authors point out that Ethiopia's real GDP per capita is likely to have grown on average by 1.3 percentage points more had the country been at a similar level of financial development as Thailand. That is, Ethiopia's average growth rate could have been $1.4 \%$ instead of $0.1 \%$, and $40 \%$ greater in 2007; over the 1980-2007 period, the ratio of private sector credit to GDP averaged $18 \%$ in Ethiopia and $87 \%$ in Thailand.

Evidence is also mounting on the thesis that financial deepening has a pro-poor effect; countries with deeper financial systems are shown to experience more rapidly declining poverty levels (Beck et al., 2007). Finance could indeed play a key role in MDGs objective of eradicating extreme poverty. Finance could play a critical role in achieving the other MDGs as well, including education, gender equality, health, environment, and global partnerships (Claessens \& Feijen, 2007).

Yet the role of finance in fostering growth in the Pacific, ironically, a region in dire need of sustainable growth and development, continues to appear less important, possibly for the reason that the relationship in the case of the region is not properly understood, due in turn to perhaps a lack of systematic empirical evidence. Extant finance-growth literature covering the region is 
not only few but also limited to studies on Fiji only (Jayaraman \& Choong, 2007; Gounder, in press). This study provides the first insight into a cross-country finance-growth relationship in the Pacific region.

Results show that finance is likely to matter for the small, open Pacific island countries (PICs) as well. Our results confirm the findings from the two country-specific Fiji studies. Policy implications emerge, including the need to properly understand the constraining and supporting factors of financial development in the unique Pacific setting. The rest of the paper is organised as follows: Section II discusses the data and methodology; Section III presents the results, with some policy implications and Section IV concludes.

\section{DATA AND METHODOLOGY}

The selection of countries is based on availability of balanced panel data for the most extensive period possible, which in this case covers the 1983-2007 period or 25 years. Time series data on PICs are particularly weak and a fairly sufficient dataset for our purpose is not available for a number of PICs. Accordingly, the countries that could be included in the study are Fiji, Papua New Guinea (PNG), Tonga and Vanuatu. While only a few, together, these countries constitute $89 \%$ of the total regional land area and $80 \%$ of the population.

Our intention is to examine the influence of financial development on economic growth. To do this, we use bank private sector credit as a ratio of GDP to measure financial development and GDP per capita to measure economic growth. Other independent variables that make up the panel include trade openness and investment to GDP ratio. With respect to openness, we use two different measures of openness; trade share ([exports + imports]/nominal GDP) and real trade share ([exports + imports]/real GDP). The data have been obtained largely from two sources: BDL's financial structure data set ${ }^{1}$ and the World Bank's database ${ }^{2}$.

Our choice of the financial development measure — bank credit to private sector - is based on the understanding that better functioning financial systems alleviate external financing constraints that may otherwise hinder firm and industrial growth and expansion, suggesting that this is a key mechanism through which finance matters for growth. Indeed, while a financial system assists in mobilising savings, transforming maturities, and capital accumulation, it is ultimately via improvements in resource allocation and productivity growth that finance helps economies grow more quickly (Beck et al., 2000; Wurgler, 2000; Love, 2003; Beck et al., 2011).

The empirical strategy is aimed at establishing an empirical model that allows the testing of the key hypothesis. To allow for the possibility of partial adjustment, we specify a dynamic equation with a lagged dependent variable. Accordingly, we estimate the following model:

$\ln G D P C_{i t}=\beta_{0}+{ }^{\prime} Y \ln G D P C_{i t-1}+\beta_{1} \ln F D_{i t}+\beta_{2} \ln O P E N_{i t}+\beta_{3} \ln I N V_{i t}+\mu_{i t}$

where, GDPC is GDP per capita, $F D$ is a measure of financial development, $O P E N$ is a measure 
of trade openness, INV is investment to GDP ratio, and $\mu$ is an error term that contains country and time specific fixed effects. And where,

$\mu_{i t}=u_{i}+\varepsilon_{t}+v_{i t}$

such that $v_{i t}$ is assumed to be independent and identically distributed with mean zero and variance $\sigma \frac{2}{v}$. All variables are used in their logarithmic forms.

Since the model includes a lagged dependent variable, the implication is that there is correlation between the regressors and the error term as lagged GDP per capita depends on $\mu_{i t-1}$ which is a function of $u_{i}$ (country specific effect) (Baltagi, et al., 2009). There is also the possibility of endogeneity arising from variables such as $F D, O P E N$ and $I N V$. To address these issues, the preferred estimator is Generalised Method of Moments (GMM) proposed by Arellano and Bond (1991). In addition, GMM allows the use of instrumental variables which produce more precise and accurate estimators. Thus, exogenous variables, the lagged dependent variable and the lagged endogenous variables are utilised as instruments. Instruments should be relevant and valid, i.e. correlated with the endogenous regressors and orthogonal to the errors (Baum et al., 2003). The over-identifying restrictions are tested via the commonly employed $J$ statistic of Hansen (1982). If the null hypothesis is rejected, it implies that the instruments are not satisfying the orthogonality conditions required. Further, in the context of GMM, the moment conditions are valid only if there is no serial correlation in idiosyncratic errors. Accepting null hypothesis at higher order, $\mathrm{AR}(2)$, implies that the moment conditions are valid.

\section{RESULTS AND POLICY IMPLICATIONS}

The results of the GMM regressions are provided in Table 1. Initially, we estimate the model with only two independent variables: GDPC lagged and $F D$, and then introduce OPEN and INV in two separate stages. Column 1 includes GDPC and FD; column 2 includes all variable in column 1 plus $O P E N$; and column 3 includes all variables in column 2 plus $I N V$. Trade share is the openness measure in columns 2 and 3 whereas real trade share is openness in columns 4 and 5. Using two proxies for openness provides additional robustness checks for the key variable, $F D$. The Hansen test shows no evidence of over identifying restrictions as the $p$ value of $J$ statistics is not significant in any of the models. The diagnostics also indicate that a negative first order autocorrelation AR (1) is present. However, second order autocorrelation is rejected as indicated by the non-significant $p$ values for $\mathrm{AR}(2)$ errors, implying that the estimates are consistent.

As Table 1 shows, the key variable in this study, $F D$, is significantly associated with GDPC across all columns, i.e. the sign and significance does not change as conditional variables are introduced into the model. Thus, finance is likely to matter for growth in the small, open Pacific 
Island Countries as well. Our findings are important for a number of reasons, including: (i) they strengthen the growing finance-growth literature; (ii) the use of the GMM technique contributes to robustness of findings, further alleviating scepticisms that may arise from shortcomings of different methods and estimation techniques; and (iii) policy implications for the Pacificfinance could indeed be an important mechanism in addressing many challenges of the Pacific, including poverty, inequality and generally the Millennium Development Goals.

TABLE 1: GMM estimates of the finance-growth relationship in the Pacific

\begin{tabular}{cccccc}
\hline Column & $\mathbf{1}$ & $\mathbf{2}$ & $\mathbf{3}$ & $\mathbf{4}$ & $\mathbf{5}$ \\
\hline $\ln \mathrm{GDPC} \mathrm{t}_{\mathrm{t}-1}$ & $0.9137^{* * *}$ & $0.88586^{* * *}$ & $0.8735^{* * *}$ & $0.8700^{* * *}$ & $0.8881^{* * *}$ \\
& $(0.0534)$ & $(0.0740)$ & $(0.0790)$ & $(0.0642)$ & $(0.0701)$ \\
$\ln \mathrm{FD}$ & $0.1011^{*}$ & $0.2903^{* *}$ & $0.2700^{* *}$ & $0.2813^{* *}$ & $0.2575^{* *}$ \\
& $(0.0595)$ & $(0.1304)$ & $(0.1349)$ & $(0.1166)$ & $(0.1219)$ \\
$\ln$ OPEN & & $0.2621^{*}$ & $0.2656^{*}$ & $-0.4709^{* *}$ & $-0.4800^{* *}$ \\
& & $(0.1358)$ & $(0.1366)$ & $(0.2262)$ & $(0.2289)$ \\
$\ln$ INV & & 0.0611 & & 0.0733 \\
& & & $(0.1369)$ & & $(0.1273)$ \\
\hline
\end{tabular}

Diagnostics (p value)

\begin{tabular}{cccccc}
$\operatorname{AR}(1)$ & 0.03 & 0.06 & 0.07 & 0.07 & 0.08 \\
$\operatorname{AR}(2)$ & 0.82 & 0.85 & 0.95 & 0.70 & 0.82 \\
Hansen J Statistic & 0.86 & 0.34 & 0.53 & 0.59 & 0.79 \\
\hline
\end{tabular}

NOTE: Standard errors are in parenthesis below the coefficient estimates. *, ** and ***indicate significance at the 10\%, 5\% and $1 \%$ levels, respectively.

With respect to policy, the overarching implication is that the financial sectors in the region may need to be developed with a view to making credit more accessible to the private sector, among others. The process of financial development, however, would need to be properly considered since as Sharma and Nguyen (2010) illustrate, with reference to the legal theory of financial development, that what may work well in one country may not necessarily be suitable for another. In any case, a good starting point would be a need to adequately understand the constraining and facilitating factors with respect to both demand and supply of private sector credit. There is a lack of depth and sophistication of the financial sector in South Pacific. Financial intermediaries generally allow a more efficient allocation of resources if all institutional innovations such as bond markets, stock markets, insurance and banking are combined to operate capably. It is also well known that the development of the financial sector helps to improve the allocation of risk in the economy and increases the efficiency of the saving and investment process. There is also the issue of financial exclusion due to price and non-price barriers. For a long time banks in South 
Pacific did not extend their operations beyond urban areas. It was only recently that rural banking through mobile banks has been made available. This can serve as a non-price barrier preventing small firms and poor households in rural areas from using financial services. The possibility of price barriers as an obstacle to financial inclusion will always be a concern towards equalising opportunities. Promoting a broader access to financial services improves overall efficiency and promotes growth and employment.

\section{CONCLUSION}

Allowing even for reverse causation, research shows via numerous cross-country, panel, and time-series estimation techniques, a strong and positive link between financial sector deepening and economic growth and development. Yet, the role of finance in fostering growth in the Pacific, ironically, a region in dire need of sustainable growth and development, continues to appear less important, possibly for the reason that the relationship in the case of the region is not properly understood, due in turn to perhaps a lack of systematic empirical evidence. Our paper therefore makes a significant contribution to the literature; it provides the first insight into a cross-country finance-growth relationship in the Pacific region.

Results show that finance is likely to matter for growth in the small, open Pacific Island Countries as well. Our findings are important for a number of reasons, including: (i) they strengthen the growing finance-growth literature; (ii) the use of the Generalised Method of Moments (GMM) estimation technique contributes to robustness of findings, further alleviating scepticisms that may arise from shortcomings of different methods and estimation techniques; and (iii) policy implications for the Pacific-finance could indeed be an important mechanism in addressing many challenges of the Pacific, including poverty, inequality and generally the Millennium Development Goals.

\section{ENDNOTES}

BDL refers to Beck, Demirguc-Kunt and Levine. Updated, on-line version of the Database is available at: http://econ. worldbank.org/WBSITE/EXTERNAL/EXTDEC/EXTRESEARCH/0,,contentMDK:20696167 pagePK:64214825 piPK:642149 43 theSitePK:469382,00.html

http://data.worldbank.org/ 


\section{REFERENCES}

Arellano, M., \& Bond, S. (1991). Some tests of specification for panel data: Monte Carlo evidence and an application to employment equations. Review of Economic Studies, 58, 277-297.

Baltagi, B., Demetriades, P., \& Law, S. H. (2009). Financial development and openness: evidence from panel data, Journal of Development Economics, 89, 285-296.

Baum, C., Schaffer, M., \& Stillman, S. (2003). Instrumental variables and GMM: estimation and testing (Working Paper No. 545). Boston College: Department of Economics

Beck, T., (2009). The Econometrics of Finance and Growth. In T. Mills \& K. Patterson (Eds.), Palgrave Handbook of Econometrics, (Vol 2, pp.1180-1211). London, Palgrave Macmillan.

Beck, T., Demirguc-Kunt, A., \& Levine, R. (2007). Finance, inequality and the poor. Journal of Economic Growth, 12, 27-49.

Beck, T., Levine, R., \& Loayza N. (2000). Finance and the sources of growth. Fournal of Financial Economics, 58, 261-300.

Beck, T., Maimbo, S. M., Faye, I., \& Triki, T. (2011). Financing Africa: Through The Crisis And Beyond. Washington D. C: World Bank.

Claessens, S., \& Feijen, E. (2007) Financial Sector Development and the Millennium Development Goals. Washington D.C: World Bank-

Jayaraman, T. K., \& Choong, C. (2007). Financial sector development and growth in Fiji: an analysis of credit boom and its implications Asia Pacific Economic fournal, 5, 1-20.

Gounder, N. (in press). Financial development and economic growth in Fiji: Fresh Empirical Evidence, Fïian Studies.

Hansen, L. (1982). Large sample properties of generalized method of moments estimators, Econometrics, 50, 1029-1054.

Levine, R. (2005). Finance and growth: theory and evidence. In P. Aghion \& S. Durlauf (Eds.), Handbook of Economic Growth (pp. 865-934). Holland: Elsevier.

Love, I. (2003). Financial development and financing constraints: international evidence from the structural investment model, Review of Financial Studies, 16, 765-91.

Sharma, P., \& Nguyen T. (2010). Law and banking development in a South Pacific island economy: the case of Fiji, 1970-2006. Journal of Asia Pacific Economy, 15, $192-216$.

Wurgler, J. (2000). Financial markets and the allocation of capital. Fournal of Financial Economics, 58, 187-214. 